\title{
The energy balance of maize production - alternative approaches
}

\author{
Tibor Horváth - Anikó Nyéki - Miklós Neményi \\ Széchenyi István University, Faculty of Agricultural and Food Sciences, \\ Department of Biosystems and Food Engineering, Mosonmagyaróvár \\ tibor.horvath.jp@gmail.com
}

\begin{abstract}
SUMMARY
Agricultural production is a crucial area, perhaps the most important for humanity. This is the only area which cannot be avoided. Therefore, it is of utmost importance to know how sustainable the system is in the long run as regards energy consumption. We have chosen the maize production sector as the main focus of this study. This crop is especially important all over the world, therefore; it requires significant input also in terms of energy. Currently, the system of maize production (as with the others) operates as an open energy system. This study aims to examine how much of the agricultural land's energy demand could be met with the help of the byproducts of 1 hectare of agricultural land - operating as a closed system, using only the remaining maize stalk and cob byproducts for energy - under the conditions of Hungarian maize production.

Energy demand is largely determined by the land's fertilizer requirement, followed by the input factor of the energy demand of the machinery during earthwork and transport.

The study assumes that the energy from the byproducts of maize production will be used exclusively with biogas technology. This can even be implemented on a county level. The final question is whether the maize production system will be able to sustain itself solely by using its own byproducts.
\end{abstract}

Keywords: energy balance, maize production, biogas, fertilizer production from biogas

\section{INTRODUCTION}

Fertilizer is an important material in modern integrated crop production and, within it, maize production. According to estimations, it would be possible to provide enough food and protein to about half the population of the world without the use of nitrogen-based fertilizers (Dawson and Hilton 2011). The growth of the world's population further increases the demand for fertilizers. The Haber-Bosch process, which is widely used today in the production of $\mathrm{N}$ based fertilizers, is based on the use of methane gas, the primary source of methane being natural gas. According to certain estimates, 1.2\% (Alghren et al. 2010) of the world's annual consumption of fossil fuels and 5\% (Hager 2014) of the world's annual natural gas consumption is used during the HaberBosch process. We must note that the Haber-Bosch process is not used exclusively in fertilizer production, but it makes up a significant portion of its use. It is necessary to use $\mathrm{e}_{\mathrm{N} \text {-fert }}=35 \mathrm{MJ} \mathrm{kg}^{-1}$ natural gas during the production of traditional $\mathrm{N}$ based fertilizer in order to produce an amount of fertilizer containing 1 kilogram of the active ingredient $\mathrm{N}$. This fossil energy demand could be decreased to a value of $2-4 \mathrm{MJ} \mathrm{kg}^{-1}$ $\mathrm{N}$ by using biogas, this difference is created by the energy demand of the biogas raw material's transport (Alghren et al. 2010). Beyond the fertilizer demand, there are other energy inputs that arise during the course of maize production, especially in the form of propellants. Current technology can provide the means for the propellant demand to be met, either directly via the biogas produced from the maize byproducts or via electricity generated from the biogas.

The study aims to explore several questions. Is it possible to realize a self-sustaining maize production system that is closed as regards energy instead of the current open system based on natural gas and fossil fuel input? If it is possible, how large an area is necessary to sustain a unit of land? Is it possible to conserve fossil energy resources and decrease $\mathrm{CO}_{2}$ emissions? We must note that apart from its main raw material, under real circumstances the production of biogas also requires other materials (eg. pig manure), but the present study discusses the possibility theoretically.

\section{MATERIAL AND METHODS}

The sum of all the defined energy input demands of all the processes of maize production provides the energy demand of the whole production process. There are extensive data available in literature on the subject.

The amount of maize production byproduct is an output of key importance to this study. As an energy source, this is the basis of the calculations.

\section{Input energy demand}

On the energy intake side, it is necessary to know the whole energy input of maize production. The study does not take into account solar energy as the largest energy input when calculating the energy balance because this is the only input that is really freely available.

Literature has dealt with the subject on several occasions, based on Pimentel's study in the USA, the full energy input demand for the production of 1 hectare of maize (taking into account the individual energy demand of manual labor, the manufacture of the machinery, diesel propellants, fertilizer, seeds, irrigation, pesticides, electricity and transport factors) is $\mathrm{e}_{\mathrm{inp}}=34,449 \mathrm{MJ} \mathrm{ha}^{-1}$ (Pimentel 2009).

Bartalos (2016) also measured and examined the energy demand of maize production on a Slovakian farm. Based on these observations the input energy demand was between 17,066 $\mathrm{MJ} \mathrm{ha}^{-1}$ and 24,508 MJ 
$\mathrm{ha}^{-1}$, depending on whether organic fertilizer was used and the kind of tillage applied (Bartalos 2016). Calculating an average this means $\mathrm{e}_{\text {inp }}=20,757 \mathrm{MJ} \mathrm{ha}^{-1}$.

The energy demand, out of all the inputs, of fertilizer production is $\mathrm{E}_{\mathrm{N} \text {-fert }}=5,250 \mathrm{MJ} \mathrm{ha}^{-1}$ when taking into account $m_{N \text {-fert }}=150 \mathrm{~kg} \mathrm{~N}$ active ingredient per ha.

If we revise this value taking into account the leakage-loss, about $r_{\text {loss.gas }}=8 \%$ of the natural gas necessary for the production of fertilizer during transport (International Energy Agency 2006, Phillips et al. 2013), then the actual fossil energy use increases to $E_{\mathrm{N} \text {-fert }}=5,760$ MJ ha ${ }^{-1}$ (Table 3.) and the total input increases to $\mathrm{E}_{\mathrm{inp}}=21,124 \mathrm{MJ} \mathrm{ha}^{-1}$ according to this equation:

$$
\mathrm{E}_{\mathrm{N} \text {-fert }}=\mathrm{m}_{\mathrm{N} \text {-fert }} \times\left(\mathrm{r}_{\text {loss.gas }} \times \mathrm{e}_{\mathrm{N} \text {-fert }}\right)
$$

The differences in data between the USA and the European studies could be due to several factors: the amount of the work intake is weighted differently, the fuel consumption calculations are different, consumption per unit taken into account in the case of machine work and transport is different.

In Pimentel's case, the total input (in this case calculating with $\mathrm{m}_{\mathrm{N}-\text { fert }}=155 \mathrm{~kg} \mathrm{ha}^{-1} \mathrm{~N}$ fertilizer (Pimentel 2009) is $\mathrm{E}_{\mathrm{inp}}=34,860 \mathrm{MJ} \mathrm{ha}^{-1}$ calculated with the amount revised with natural gas' loss.

This study is based on the data of Bartalos (2016), which is closest to Hungarian agricultural practices, but for the sake of comparison, I will also calculate the possibilities using Pimentel's values.
Maize production's yield, the amount of usable byproduct

Pimentel's study calculates with a grain yield of $Y_{\text {grain }}=9,400 \mathrm{~kg} \mathrm{ha}^{-1}$, taking USA data into account (Pimentel 2009). Bartalos takes into account the data of the Slovakian Csilizköz Rt. in the year 2015 with a quantified grain of $\mathrm{Y}_{\text {grain }}=8,887 \mathrm{~kg} \mathrm{ha}^{-1}$ (based on a $15 \%$ dry matter content $\left.-f_{\text {grain }}=0.15\right)($ Bartalos 2016).

Based on the Hungarian Central Statistical Agency data series, the average maize grain yield in Hungary in the past 3 years, calculating with the whole country is $Y_{\text {grain }}=7,413 \mathrm{~kg} \mathrm{ha}^{-1}$ assuming $15 \%$ moisture content (Hungarian Central Statistical Agency 2017). From here, this data will be used for calculations.

Assuming a 1:1 stalk/grain ratio in dry material $\left(\mathrm{r}_{\text {stalk }}=1.0\right), \mathrm{a}$

$$
\mathrm{Y}_{\text {grain.dry }}=\mathrm{Y}_{\text {grain }} \times\left(1-f_{\text {grain }}\right) \times \mathrm{r}_{\text {stalk }}=6,301 \mathrm{~kg} \mathrm{ha}^{-1}
$$

mass of byproducts are generated during the course of production in Hungary.

The present study's model aims to examine the theoretical supply possibilities for the entire maize production process by using this byproduct as an energy source.

\section{RESULTS AND DISCUSSION}

\section{The energy balance of maize production}

If we look at the energy balance of maize production (Table 1), we can see the following results.

In the case of fossil fuel based energy, the energy balance for the whole plant according to Table 1 is $\mathrm{E}_{\text {out.norm }} / \mathrm{E}_{\text {inp.norm }}=9.89$. We must also note that this contains the solar energy that the plant utilizes during its lifetime.

Table 1

\begin{tabular}{|c|c|c|c|}
\hline & & Under Hungarian conditions & Based on Pimentel's data \\
\hline \multirow{5}{*}{ Outputs } & Amount of grain yield (15\% moisture content) $\left(\mathrm{Y}_{\text {grain }}\right)$ & $7,413 \mathrm{~kg} \mathrm{ha}^{-1}$ & $9,400 \mathrm{~kg} \mathrm{ha}^{-1}$ \\
\hline & Amount of maize stalk and $\operatorname{cob}\left(\mathrm{Y}_{\text {stalk.dry }}\right)$ & $6,301 \mathrm{~kg}$ dry material $\mathrm{ha}^{-1}$ & $7,990 \mathrm{~kg}$ dry material ha ${ }^{-1}$ \\
\hline & Energy content of grain $\left(\mathrm{E}_{\text {grain.dry }}\right)^{\mathrm{a}}$ & $111,195 \mathrm{MJ}$ & $141,000 \mathrm{MJ}$ \\
\hline & Energy content of maize stalk and cob $\left(E_{\text {grain.dry }}\right)^{b}$ & $97,666 \mathrm{MJ}$ & $123,845 \mathrm{MJ}$ \\
\hline & Total output $\left(\mathrm{E}_{\text {out.norm }}\right)^{\mathrm{c}}$ & $208,861 \mathrm{MJ}$ & $264,845 \mathrm{MJ}$ \\
\hline Inputs & Total energy input in the case of traditional method ( $\left.\mathrm{E}_{\text {inp.norm }}\right)$ & $21,124 \mathrm{MJ}$ & $34,860 \mathrm{MJ}$ \\
\hline \multicolumn{2}{|c|}{$\mathrm{E}_{\text {out norm }} / \mathrm{E}_{\text {inp norm }}$} & 9.89 & 7.60 \\
\hline
\end{tabular}

The energy balance of maize production for 1 hectar

Note: ${ }^{a} \mathrm{E}_{\text {grain.dry }}=\mathrm{Y}_{\text {grain }} \times\left(1-f_{\text {grain }}\right) \times \mathrm{e}_{\text {grain.dry, }}$, where $\mathrm{e}_{\text {grain.dry }}=15.0 \mathrm{MJ} \mathrm{kg}^{-1}$ - energy content of grain.

Note: ${ }^{b} E_{\text {stalk.dry }}=Y_{\text {stalk.dry }} \times e_{\text {stalk.dry, }}$, where $e_{\text {stalk.dry }}=15.5 \mathrm{MJ} \mathrm{kg}^{-1}$ - energy content of stalk.

Note: ${ }^{\mathrm{c}} \mathrm{E}_{\text {out.norm }}=\mathrm{E}_{\text {stall.dry }}+\mathrm{E}_{\text {grain.dry }}$

\section{Producing biogas from stalks}

Based on the initial data $Y_{\text {stalk.dry }}=6,301 \mathrm{~kg}$ dry matter $\mathrm{ha}^{-1}$ stalks and cobs can be collected.

Knowing the calorific value $\left(\mathrm{H}_{\text {biogas }}=21.48 \mathrm{MJ} \mathrm{m}^{-3}\right)$, the energy content of the biogas produced from the byproducts of 1 ha land can be determined (Table 2).

\section{Fertilizer production from biogas}

Empirically, I calculated the amount of fertilizer used during maize production as $m_{N-\text { fert }}=150 \mathrm{~kg} \mathrm{ha}^{-1}$ for the calculations modelling Hungarian conditions (In the Slovakian example Bartalos calculates with
$152 \mathrm{~kg} \mathrm{ha}^{-1}$ and in the American example Pimentel uses $155 \mathrm{~kg} \mathrm{ha}^{-1}$. According to Alghren et al. (2010) the production of $1 \mathrm{~kg} \mathrm{~N}$ fertilizer has an energy input demand of $\mathrm{e}_{\mathrm{N} \text {-fert }}=35 \mathrm{MJ}$, provided that current, up-todate technology is used and that the factory's only type of input is natural gas (or biogas) and the only output product is $\mathrm{N}$ based fertilizer and waste energy (eg. waste-heat).

According to the data in international literature, loss during the transportation of natural gas from the point of production to the point of utilization must always be taken into account. According to the USA 
data of the University of Boston (Phillips et al. 2013) and the International Energy Agency's study on Russian gas transportation (International Energy Agency 2006), this loss is 3-8\%. Although it can be determined, sometimes the supplier itself makes it difficult to ascertain the true rate of loss, because this amount means an enormous deficit and environmental damage even on a regional level, not to mention if we were to examine it on a global scale. The International Energy Agency - in the case of Russian gas and the research team at the University of Boston - both mention that the data published by suppliers probably greatly underestimates the real rate of leakage-loss. For this reason, I calculated with the highest value, $8 \%$, in my study $\left(\mathrm{r}_{\text {loss.gas }}=1.08\right)$.

The biogas yield of maize production byproducts

\begin{tabular}{|c|c|c|c|}
\hline & Under Hungarian conditions & Based on Pimentel's data & Source \\
\hline $\begin{array}{l}\text { Biogas yield for dry material in } \\
\left.\text { the case of stalks ( } v_{\text {biogas.stalk }}\right)\end{array}$ & $4201 \mathrm{~kg}^{-1}$ dry matter & $4201 \mathrm{~kg}^{-1}$ dry matter & $\begin{array}{l}\text { Kacz (2008), Chamber of Commerce and } \\
\text { Industry Csongrád County (2011) }\end{array}$ \\
\hline $\begin{array}{l}\text { Biogas yield for maize stalks } \\
\text { harvested from } 1 \text { ha }\left(\mathrm{V}_{\text {biogas }}\right)^{\mathrm{a}}\end{array}$ & $2646.4 \mathrm{~m}^{3} \mathrm{ha}^{-1}$ & $3355.8 \mathrm{~m}^{3} \mathrm{ha}^{-1}$ & calculated value \\
\hline
\end{tabular}

Note: ${ }^{\mathrm{a}} \mathrm{V}_{\text {biogas }}=\mathrm{Y}_{\text {stalk.dry }} \times \frac{v_{\text {biogas,stalk }}}{1,000}$

This value must be taken into account when determining each of the inputs, as I have indicated in the initial data (Table 3).

If the fertilizer is produced from natural gas, then in the case of maize production under Hungarian conditions the use of $\mathrm{N}$ fertilizer necessary for 1 ha of land accounts for $26.84 \%$ of the entire input demand (Table 4).

\section{Energy demand in the case of an energy supply based solely on biogas}

The energy demand of the whole process was traditionally $\mathrm{E}_{\text {inp.norm }}=21,124 \mathrm{MJ} \mathrm{kg}^{-1}$. If we subtract the production of $\mathrm{N}$ based fertilizer, then the remaining demand is $E_{\text {inp.cultivation }}=15,454 \mathrm{MJ} \mathrm{kg}^{-1}$. In the case of $100 \%$ biogas based energy input,

$$
\mathrm{D}_{\text {biogas.cultivation }}=\frac{\frac{E_{\text {inp,cultivation }}}{h_{\text {biogas }}}}{\eta_{\text {biogas }}}=799.42 \mathrm{~m}^{3}
$$

biogas is needed. The energy demand of wrapping and transport connected to the production of $100 \%$ biogas based fertilizer must be added to this, this is $\mathrm{E}_{\text {inp.transport }}=1,231.7 \mathrm{MJ} \mathrm{ha}^{-1}$ (Table 4), which can be supplied by $D_{\text {biogas.transport }}=63.71 \mathrm{~m}^{3}$ biogas. Apart from this, $D_{\text {biogas.fert }}=245.4 \mathrm{~m}^{3}$ biogas is needed to produce the fertilizer itself.

For the process I am calculating with $10 \%$ loss for all uses of biogas, excluding the Haber process of fertilizer production. Thus, the full biogas demand is, as Table 5 shows, $\mathrm{D}_{\text {biogas.production }}=\mathrm{D}_{\text {biogas.cultivation }}+$ $D_{\text {biogas.fert }}+D_{\text {biogas.transport }}=1,108.58 \mathrm{~m}^{3}$ ha $^{-1}$.

We can calculate from the data above that with the help of byproducts harvested from 1 ha, the energy demand for the production of 2.39 ha maize can be supplied.

The energy input demand of $\mathbf{N}$ fertilizer in the case of natural gas

\begin{tabular}{|c|c|c|c|}
\hline & $\begin{array}{c}\text { Under } \\
\text { Hungarian } \\
\text { conditions }\end{array}$ & $\begin{array}{c}\text { Based on } \\
\text { Pimentel's } \\
\text { data }\end{array}$ & Source \\
\hline $\begin{array}{l}\text { The energy content of natural gas necessary for } \\
1 \mathrm{~kg} \mathrm{~N} \text { fertilizer }\left(\mathrm{e}_{\mathrm{N} \text {-fert }}\right)\end{array}$ & \multicolumn{2}{|c|}{$35 \mathrm{MJ}$} & Alghren et al. (2010) \\
\hline $\begin{array}{l}\text { Loss of natural gas during transportation within } \\
\text { the full network }\left(\mathrm{r}_{\text {loss.gas }}\right)\end{array}$ & \multicolumn{2}{|c|}{$8.00 \%$} & $\begin{array}{c}\text { Based on International Enegry Agency (2006) } \\
\text { Phillips et al. (2013) }\end{array}$ \\
\hline $\begin{array}{l}\text { Actual input energy consumption in the case of } \\
\text { natural gas use - including loss }\left(\mathrm{e}_{\mathrm{N} \text {-fert }} \times \mathrm{r}_{\text {loss.gas }}\right)\end{array}$ & \multicolumn{2}{|c|}{$37.8 \mathrm{MJ}$} & calculated value \\
\hline $\begin{array}{l}\text { The amount of } \mathrm{N} \text { fertilizer necessary for the production of } \\
1 \text { ha maize }\left(\mathrm{m}_{\mathrm{N} \text {-fert }}\right)\end{array}$ & $150 \mathrm{~kg}$ & $155 \mathrm{~kg}$ & \\
\hline $\begin{array}{l}\text { The energy demand for the production of the amount of } \\
\mathrm{N} \text { fertilizer necessary for the production of } 1 \text { ha maize }\left(\mathrm{E}_{\mathrm{N}-\text { fert }}\right)^{\mathrm{a}}\end{array}$ & $5,670 \mathrm{MJ}$ & $5,859 \mathrm{MJ}$ & calculated value \\
\hline
\end{tabular}

Note: ${ }^{a} E_{N-\text { fert }}=m_{N-\text { fert }} \times\left(r_{\text {loss.gas }} \times \mathrm{e}_{\mathrm{N} \text {-fert }}\right)$ 
The energy input demand of $\mathbf{N}$ fertilizer in the case of biogas

\begin{tabular}{|c|c|c|c|}
\hline & $\begin{array}{l}\text { Under Hungarian } \\
\text { conditions }\end{array}$ & $\begin{array}{c}\text { Based on } \\
\text { Pimentel's data }\end{array}$ & Source \\
\hline Methane demand of $1 \mathrm{~kg} \mathrm{~N}$ fertilizer ${ }^{\mathrm{a}}\left(\mathrm{d}_{\mathrm{CH}_{4} \text { fert }}\right)$ & \multicolumn{2}{|c|}{$0.981 \mathrm{~m}^{3} \mathrm{~kg}^{-1}$} & Alghren et al. (2010) \\
\hline $\begin{array}{l}\text { Amount of biogas used for the production of } \\
1 \mathrm{~kg} \mathrm{~N} \text { fertilizer }{ }^{\mathrm{b}}\left(\mathrm{d}_{\text {biogas.fert }}\right)\end{array}$ & \multicolumn{2}{|c|}{$1.636 \mathrm{~m}^{3} \mathrm{~kg}^{-1}$} & calculated value based on the biogas' data \\
\hline Biogas demand for $\mathrm{N}$ fertilizer $\left(\mathrm{D}_{\text {biogas.fert }}\right)^{\mathrm{c}}$ & $245.4 \mathrm{~m}^{3}$ & $253.6 \mathrm{~m}^{3}$ & calculated value \\
\hline $\begin{array}{l}\text { Input energy demand due to wrapping and transport } \\
\text { because of biogas raw material }{ }^{\mathrm{d}}\left(\mathrm{E}_{\text {transport }}\right)\end{array}$ & $1,231.7 \mathrm{MJ} \mathrm{ha}^{-1}$ & 1,657.1 $\mathrm{MJ} \mathrm{ha}^{-1}$ & calculated value \\
\hline $\begin{array}{l}\text { - this supported by the use of biogas } \\
\text { (taking into account } 10 \% \text { loss) }\left(\mathrm{D}_{\text {biogas.transport }}\right)^{\mathrm{e}}\end{array}$ & $63.71 \mathrm{~m}^{3} \mathrm{ha}^{-1}$ & $85.72 \mathrm{~m}^{3} \mathrm{ha}^{-1}$ & calculated value \\
\hline
\end{tabular}

Note: ${ }^{a}$ In the case of $35 \mathrm{MJ}$ full natural gas energy input demand, of which the methane content is $f_{\mathrm{CH}_{4} \text {.gas }}=97 \%$ and its calorific value is $\mathrm{h}_{\mathrm{gas}}=34.58 \mathrm{MJ} \mathrm{m}^{-3}$ (Tóth et al. 2011).

Note: ${ }^{\mathrm{b}}$ The methane content of the produced biogas is $f_{\mathrm{CH}_{4} \text {.biogas }}=60 \%$ and the equation is the following:

Note: ${ }^{c} \mathrm{D}_{\text {biogas.fert }}=\mathrm{d}_{\text {biogas.fert }} \times \mathrm{m}_{\mathrm{N} \text {-fert. }}$.

$$
d_{\text {biogas,fert }}=\frac{d_{C H 4, \text { fert }}}{f_{C H 4, \text { biogas }}}=\frac{\frac{e_{N-\text { fert }}}{h_{\text {gas }}} \times f_{C H 4, \text { gas }}}{f_{C H 4, \text { biogas }}}
$$

Note: ${ }^{\mathrm{d}}$ In our case I calculated using Gockler's equivalent - for harvesting and transportation, which is in line with Hungarian conditions. According to this, the amount of gas oil needed for wrapping and bale-packaging is $14.4 \mathrm{~kg} \mathrm{ha}^{-1}$ and $6 \mathrm{~kg} \mathrm{tkm}^{-1}$ for $50 \mathrm{~km}$ of road transportation (Gockler 2013).

Note: ${ }^{\mathrm{e}} D_{\text {biogas,transport }}=\frac{\frac{E_{\text {transport }}}{h_{\text {biogas }}}}{\eta_{\text {biogas }}}$, where the calorific value of biogas is $h_{\text {biogas }}=21.48 \mathrm{MJ} \mathrm{m}^{-3}$, and the efficiency of biogas usage is $\eta_{\text {biogas }}=0.9$.

Input values of the production of 1 ha of maize using their own byproducts based on $100 \%$ biogas input

\begin{tabular}{|c|c|c|}
\hline & $\begin{array}{l}\text { Under Hungarian } \\
\text { conditions }\end{array}$ & $\begin{array}{c}\text { Based on } \\
\text { Pimentel's data }\end{array}$ \\
\hline $\begin{array}{l}\text { Energy inputs with the exception of } \mathrm{N} \text { fertilizer production } \\
\left(\mathrm{E}_{\text {inp.cultivation }}\right)\end{array}$ & $15,454.4 \mathrm{MJ} \mathrm{ha}^{-1}$ & $29,001.0 \mathrm{MJ} \mathrm{ha}^{-1}$ \\
\hline $\begin{array}{l}-\quad \text { amount of biogas necessary for this } \\
\left(D_{\text {biogas.ultivation }}\right)\end{array}$ & $799.42 \mathrm{~m}^{3} \mathrm{ha}^{-1}$ & $1,500.15 \mathrm{~m}^{3} \mathrm{ha}^{-1}$ \\
\hline $\begin{array}{l}\text { The amount of maize stalk necessary for the production of fertilizer } \\
\text { (D biogas.fert })\end{array}$ & $245.45 \mathrm{~m}^{3} \mathrm{ha}^{-1}$ & $253.63 \mathrm{~m}^{3} \mathrm{ha}^{-1}$ \\
\hline $\begin{array}{l}\text { The amount of maize stalk necessary for the energy demand of wrapping and transport } \\
\left(D_{\text {biogas.transport }}\right)\end{array}$ & $63.71 \mathrm{~m}^{3} \mathrm{ha}^{-1}$ & $85.72 \mathrm{~m}^{3} \mathrm{ha}^{-1}$ \\
\hline $\begin{array}{l}\text { The full biogas demand in the case of a } 100 \% \text { biogas based production process } \\
\text { ( } D_{\text {biogas.production }} \text { ) }\end{array}$ & $1,108.58 \mathrm{~m}^{3} \mathrm{ha}^{-1}$ & $1,839.50 \mathrm{~m}^{3} \mathrm{ha}^{-1}$ \\
\hline $\begin{array}{l}\text { The amount of maize stalk necessary for the production of the full biogas amount } \\
\left(\mathrm{M}_{\text {stalk.demand })^{\mathrm{a}}}\right.\end{array}$ & $2,639.5 \mathrm{~kg}$ & $4,379.8 \mathrm{~kg}$ \\
\hline 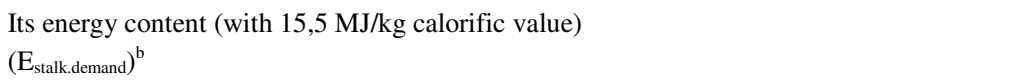 & $40,912 \mathrm{MJ}$ & $67,886 \mathrm{MJ}$ \\
\hline How many hectares' full input can the total amount of maize stalk produce on 1 ha supply? & $2.39 \mathrm{ha}$ & $1.82 \mathrm{ha}$ \\
\hline
\end{tabular}

Note: ${ }^{\mathrm{a}} \mathrm{M}_{\text {stalk.demand }}=\frac{D_{\text {biogas,production }}}{\frac{v_{\text {biogas,stalk }}}{1,000}}$

Note: ${ }^{\mathrm{b}} \mathrm{E}_{\text {stalk.demand }}=\mathrm{M}_{\text {stalk.demand }} \times \mathrm{e}_{\text {stalk.dry }}$

The energy rate of maize production under $100 \%$ biogas-sourced production

If the whole maize production process's energy input is $100 \%$ biogas, then the transport loss that occurs in the case of natural gas does not need to be taken into account when calculating the energy rate of maize production, but the additional energy demand deriving from the transportation of biogas raw materials must be added to the inputs.

A further significant factor is that due to the system not receiving an external energy source (as earlier, eg. natural gas, electricity or fossil diesel propellant) and instead extracting the raw materials necessary for input from the system itself, in the form of maize stalks and maize cobs, it cannot be taken into account on the output side.

Based on data from literature, I assumed that the output/input energy balance of biogas production was 2.56:1, that is, every $\mathrm{MJ}$ of delivered energy is enough for the production of $2.56 \mathrm{MJ}$ biogas. Thus, a delivered energy of $1 / 2.56$ of the calorific value of all the needed biogas is necessary for the maintenance of the system. 


\section{CONCLUSIONS}

Based on the results it is apparent that when using a production model that is $100 \%$ free of fossil energy, a higher energy rate can be achieved than in the case of a fossil energy based system. The energy rate of the entire system was 9.89 to 18.31 (Table 6) in the case of the model taking Hungarian basic data into account, whilst in the case of the calculations taking American data into account, it increases from 7.60 to 11.34. Based on the model the remaining stalks and husks from 1 ha of maize can be used to supply 1.8-2.3 ha with energy in a closed system.

The energy demand of maize production in the case of $100 \%$ biogas sourced production

\begin{tabular}{|c|c|c|c|}
\hline & & $\begin{array}{l}\text { Under Hungarian } \\
\text { conditions }\end{array}$ & $\begin{array}{c}\text { Based on } \\
\text { Pimentel's data }\end{array}$ \\
\hline Energy outputs & Total outputs $\left(\mathrm{E}_{\text {out.bio }}\right)^{\mathrm{a}}$ & $170,301 \mathrm{MJ} \mathrm{ha}^{-1}$ & $264,845 \mathrm{MJ} \mathrm{ha}^{-1}$ \\
\hline \multirow{3}{*}{ Energy inputs } & Full biogas demand for the whole production process $\left(\mathrm{D}_{\text {biogas.production }}\right)$ & $1,108.58 \mathrm{~m}^{3} \mathrm{ha}^{-1}$ & $1,839.50 \mathrm{~m}^{3} \mathrm{ha}^{-1}$ \\
\hline & Total calorific value of biogas $\left(\mathrm{H}_{\text {biogas.production }}\right)^{\mathrm{b}}$ & $23,812.4 \mathrm{MJ} \mathrm{ha}^{-1}$ & $39,512.4 \mathrm{MJ} \mathrm{ha}^{-1}$ \\
\hline & - delivered input energy for this biogas $\left(\mathrm{E}_{\text {input biogas.process }}\right)^{\mathrm{c}}$ & 9,301.7 $\mathrm{MJ} \mathrm{ha}^{-1}$ & 17,561.1 $\mathrm{MJ} \mathrm{ha}^{-1}$ \\
\hline \multicolumn{2}{|c|}{$\mathrm{E}_{\text {out.bio }} / \mathrm{E}_{\text {input.biogas.process }}$} & 18.31 & 11.39 \\
\hline \multicolumn{4}{|c|}{$\begin{array}{l}\text { Note: }{ }^{b} \mathrm{H}_{\text {biogas.production }}=\mathrm{D}_{\text {biogas.production }} \times \mathrm{h}_{\text {biogas }} \\
\text { Note: }{ }^{\mathrm{c}} \mathrm{E}_{\text {input.biogas.process }}=\frac{H_{\text {biogas,production }}}{256}\end{array}$} \\
\hline
\end{tabular}

Several important things must be noted in connection with the model:

- The model presently calculates biogas production only from maize stalks in the case of $100 \%$ biogas based input. In practice, other materials are needed as well (eg. pig manure or other materials).

- The model does not take into account the possibility of how much of a biomass increase can be achieved in the case of the return of residual fermentation liquid and silt (as nutrients) from the process of biogas production.
Further studies could be carried out based on these factors.

\section{ACKNOWLEGDEMENTS}

This research was supported by VKSZ-12-1-20130034 "Agricultural Climate" Competitiveness and Excellence Contract, and supported by the EFOP3.6.3-VEKOP-16-2017-00008 project. The project is co-financed by the European Union and the European Social Fund.

\section{REFERENCES}

Ahlgren, S.-Bernesson, S.-Nordberg, K.-Hansson, P. A. (2010): Nitrogen fertiliser production based on biogas - Energy input, environmental impact and land use. Bioresource Technology. 9: 7181-7184.

Bartalos G. (2016): Szántóföldi növénytermesztés energia mérlege, különös tekintettel az őszi búzára és kukoricára. Széchenyi István Egyetem Mezőgazdasági és Élelmiszeripari Kar. Biológiai Rendszerek és Élelmiszeripari Müszaki Tanszék. Szakdolgozat. Mosonmagyaróvár. 36.

Chamber of Commerce and Industry Csongrád County (2011) Tanulmány a biogáz-termeléslehetőségeiről a Temes és Csongrád megye határmenti régióban.

Dawson, C. J.-Hilton, J. (2011): Fertiliser availability in a resourcelimited world: Production and recycling of nitrogen and phosphorus. Food Policy. 36. Supplement 1: S14-S22.

Gockler L. (2013): Mezőgazdasági gépi munkák költsége 2013-ban. Mezőgazdasági Gépesítési Intézet. Gödöllő.
Hager, T. (2014): Feeding a hungry world - IFDC's First Forty Years. International Fertilizer Development Center. Alabama. USA. 108.

International Energy Agency (2006): Optimising Russian Natural Gas. OECD/IEA.

Kacz K. (2008): A biomassza hasznosítása biogáz formában. Renewable Energy Textbook. Nyugat-magyarországi Egyetem MÉK Biológiai Rendszerek Műszaki Intézete. 4. 25-30.

KSH - Hungarian Central Statistical Agency: Idősoros éves területi adatok, 6.4.1.5. táblázat: A kukorica termelése (2000-).

Phillips, N. G.-Ackley, R.-Crosson, E.R.-Down, A.-Hutyra, L. R.Brondfield, M.-Karr, J. D.-Zhao, K.-Jackson, R. B. (2013): Mapping urban pipeline leaks: Methane leaks across Boston. Environmental Pollution. 173: 1-4.

Pimentel, D. (2009): Energy Inputs in Food Crop Production in Developing and Developed Nations. Energies. 2. 6: Table 5.

Tóth P.-Bulla M.-Nagy G. (2011): Energetika. A földgáz tipikus összetétele. 184. 7.1. táblázat. 